
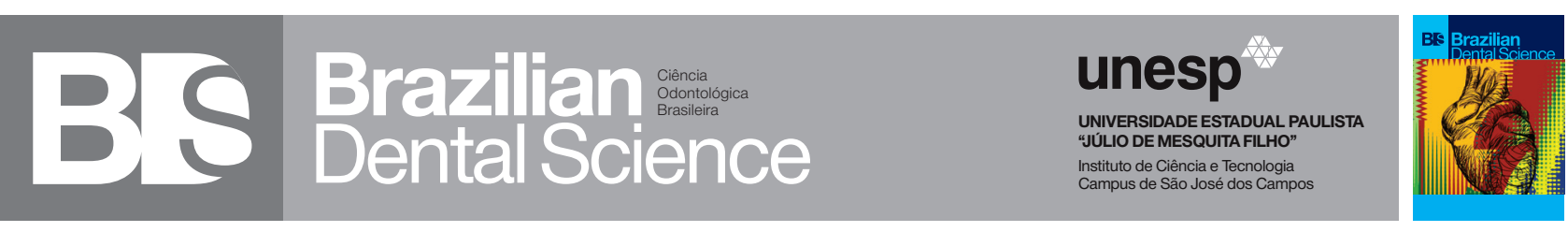

\title{
Effect of glide path on transportation promoted by NiTi and M-Wire instruments
}

\author{
Efeito do glide path no transporte promovido por instrumentos de NiTi e M-Wire
}

Tatiane Pires NOGUEIRA ${ }^{1}$, Ellen Roberta Lima BESSA ${ }^{1}$, Eduardo da Costa NUNES ${ }^{2}$, André Augusto Franco MARQUES ${ }^{1,3}$, Lucas da Fonseca Roberti GARCIA ${ }^{4}$, Fredson Márcio Acris de CARVALHO ${ }^{1,3}$

1 - Superior School of Health Sciences - State University of Amazonas - Manaus - AM - Brazil.

2 - School of Dentistry - Federal University of Amazonas - Manaus - AM - Brazil.

3 - UniNorte - Laureate International Universities - Manaus - AM - Brazil.

4 - Department of Dentistry - Endodontics Division - Health Sciences Center - Federal University of Santa Catarina - Florianópolis - SC - Brazil.

\begin{abstract}
Objective: To evaluate the effect of glide path creation on transportation promoted by NiTi and M-Wire instruments. Material and Methods: Sixty polyester resin blocks containing a simulated root canal were distributed into four groups ( $\mathrm{n}=15)$, according to the protocols/systems used for root canal preparation: GPR group - glide path + Revo-S system; R group - no glide path + Revo-S system; GPPN group - glide path + ProTaper Next system and PN group - no glide path + ProTaper Next system. Root canals were photographed before and after preparation, and the images were superimposed to evaluate the transportation at the apical, middle and coronal thirds. The time spent to perform preparation was also measured (seconds). Data were submitted to the non-parametric Kruskal-Wallis test $(\mathrm{p}<0.05)$ for statistical analysis. Results: In the apical third, there was no significant difference among groups ( $>0.05$ ). GPR and R groups were similar in the middle third $(p>0.05)$. However, the transportation value in GPR group was statistically higher in comparison with GPPN and PN groups $(\mathrm{p}<0.05)$. In the coronal third, GPR and R groups were similar $(p>0.05)$. Only $R$ group presented significant difference in comparison with GPPN and PN groups $(\mathrm{p}<0.05)$. There was no difference among groups about time spent to perform preparation ( $p>0.05)$. Conclusion: None of the systems were capable of maintaining the original trajectory of the simulated root canal, and the glide path had no effect on the transportation promoted by instruments.
\end{abstract}

\section{KEYWORDS}

Dental instruments; Endodontics; Root canal preparation.

\section{RESUIMO}

Objetivo: Avaliar o efeito do glide path no transporte promovido por instrumentos fabricados em NiTi e M-Wire. Material e Métodos: Sessenta blocos de resina poliéster contendo um canal simulado foram separados em quatro grupos ( $\mathrm{n}=15)$, de acordo com os protocolos/ sistemas utilizados para realização do preparo: Grupo GPR - glide path + sistema Revo-S; Grupo R - sem glide path + sistema Revo-S; Grupo GPPN - glide path + sistema ProTaper Next e Grupo PN - sem glide path + sistema ProTaper Next. Os canais foram fotografados antes e após o preparo, e as imagens sobrepostas para avaliação do transporte nos terços apical, médio e cervical. O tempo para realização do preparo também foi mensurado (segundos). Os dados foram submetidos ao teste não-paramétrico de Kruskal-Wallis $(\mathrm{p}<0,05)$ para análise estatística. Resultados: No terço apical não houve diferença significante entre os grupos ( $>0,05)$. Os grupos GPR e R foram semelhantes no terço médio ( $>0,05$ ), entretanto, o transporte no grupo GPR foi estatisticamente maior em comparação aos grupos GPPN e P $(p<0,05)$. No terço cervical, os grupos GPR e R foram semelhantes ( $>00,05)$. Somente o grupo $R$ apresentou diferença em comparação aos grupos GPPN e PN $(p<0,05)$. Não houve diferença entre os grupos em relação ao tempo $(p>0,05)$. Conclusão: Nenhum sistema foi capaz de manter a trajetória original do canal simulado, e o glide path não teve efeito sobre o transporte promovido pelos instrumentos.

\section{PALAVRAS-CHAVE}

Endodontia; Instrumentos odontológicos; Preparo de canal radicular. 


\section{INTRODUCTION}

B iomechanical preparation is one of the most critical stages of endodontic therapy [1]. The anatomic complexity of root canals makes this procedure a constant challenge to professionals, despite the advances obtained over the last few years with the development of new instrumentation systems and techniques [2].

Atretic root canals and those with severe curvature degrees favor the appearance of undesirable accidents during the operating procedures [3,4]. NiTi instruments have emerged as an alternative for reducing the incident of such accidents, since their mechanical characteristics, as high flexibility and elasticity, facilitate root canals preparation [5].

New systems for biomechanical preparation, such as those manufactured with M-Wire technology, have increased the flexibility and resistance to cyclic and torsional fatigue of instruments, in comparison with the conventional NiTi instruments [6]. M-Wire instruments undergo a thermomechanical treatment, in which the martensistic phase of the NiTi alloy is transformed into the austenitic phase, followed by reversion to martensitic phase after stress removal [6]. This manufacturing process gives to the instruments superelasticity, allowing preparation of root canals of different anatomical complexities [6].

Rotary systems that use a reduced number of instruments, such as Revo-S (MicroMega, Besançon, France) and ProTaper Next (Dentsply/Maillefer, Ballaigues, Switzerland) - fabricated of conventional NiTi and M-Wire, respectively, are available on the market [7]. The primary purpose of these systems is to simplify endodontic treatment since few instruments are required to perform root canal preparation [7]. However, due to the reduced number of instruments used, a proper glide path must be created before rotary instruments action, to ensure their free advance along the entire length of the root canal [8-10].

Therefore, the objective of this study was to evaluate the effect of the glide path creation on transportation promoted by NiTi (Revo-S) and M-Wire (ProTaper Next) instruments in the cervical, middle and apical thirds of simulated root canals. The null hypothesis tested was that the glide path created would not interfere with the performance of the rotary system.

\section{METHODS AND MATERIALS}

Sixty transparent polyester resin blocks containing a simulated root canal (IM do Brasil Ltda. São Paulo, SP, Brazil), measuring $16-\mathrm{mm}$ long, with a $30^{\circ}$ angle of curvature and a $3-\mathrm{mm}$ radius of curvature, were used in this study (Figure 1). A size $10 \mathrm{~K}$-file (Dentsply/ Maillefer) was introduced in the simulated root canal to determine the working length, which it was standardized at $15 \mathrm{~mm}$. Next, the simulated root canals were randomly distributed into four groups $(n=15)$, according to the systems and protocols used to perform biomechanical preparation.

- Group GPR: glide path creation with sizes 10 and 15 K-files (Dentsply/ Maillefer) up to the working length, followed by preparation with Revo-S system, according to the manufacturer's instructions instruments SC1 $(0.25 / 0.06)$ at $2 / 3$ of working length, SC2 $(0.25 / 0.04)$ and SU $(0.25 / 0.06)$ up to the working length. SC1 was used in a slow-downward movement, with no apical pressure. SC2 was used in progressive 3 -wave movements (back-and-forth); and SU was used 
as SC1 instrument. The instruments were coupled to a 6:1 handpiece device (VDW Silver Reciproc, Sirona Dental Systems $\mathrm{GmbH}$, Bensheim, Germany), driven by an electric motor (VDW Silver Reciproc Motor, Sirona Dental Systems), at $300 \mathrm{rpm}$ and torque of 0.8 N.cm, in accordance with the manufacturer's recommendation.

- Group R: no glide path creation. The simulated root canals were prepared as described in Group 1.

- Group GPPN: glide path creation with sizes 10 and 15 K-files (Dentsply/Maillefer) up to the working length, followed by preparation with ProTaper Next system, according to the manufacturer's instructions instruments X1 (0.17/0.04) and X2 (0.25/0.06) up to the working length. X1 and X2 instruments were used gently, with backand-forth movements, until the working length was reached. They were coupled to a 6:1 handpiece device (VDW Silver Reciproc), driven by an electric motor (VDW Silver Reciproc Motor), at 250 $\mathrm{rpm}$, as recommended by the manufacturer.

- Group PN: no glide path creation. The simulated root canals were prepared as described in Group 3.
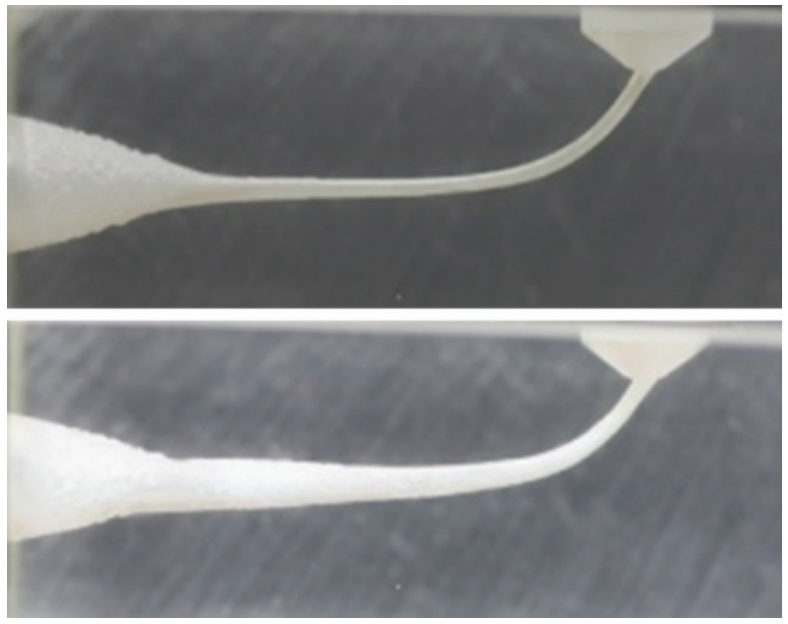

Figure 1 - Transparent polyester resin block containing a simulated root canal. Before preparation (above), and after preparation (below).

After each insertion of the instruments, they were removed from the simulated root canals and cleaned with sterile gauze. The irrigation was performed with $2 \mathrm{~mL}$ of $2.5 \%$ sodium hypochlorite solution (Rio Química, São José do Rio Preto, SP, Brazil) at each advance and removal of the instruments within the root canal. For this purpose, a disposable plastic syringe (EndoEze, Ultradent Products Inc., South Jordan, UT, USA) with a 29-gauge needle $(0.29 \mathrm{~mm})$ (NaviTip, Ultradent Products Inc.) was used. At the end of the root canal preparation, the excess of sodium hypochlorite solution was aspired entirely (CapillaryTip, Utradent Products Inc.) from the simulated root canals. A new set of instruments (K-files, Revo-S, and ProTaper Next system) was used after performing the preparation of five simulated root canals. All the procedures described above were performed by only one operator, a specialist in endodontics, and previously calibrated in a pilot study. 
The time required for the instruments of the different groups to attain the working length was recorded with the aid of an electronic digital stopwatch (Oregon Scientific - S1928m, Portland, OR, USA) and expressed in seconds (s). The time required to perform the irrigation and use of manual instruments to create the glide path was not considered.

To analyze transportation, the polyester resin blocks were photographed (Canon EOS D600, Lake Success, NY, USA). To standardize the images before and after preparation, the resin blocks were coupled to a polystyrene platform that kept them at the same position. The initial and final images were then colored in blue and red, respectively, and superimposed on each other (Figure 2a). The distance between the external and internal wall of the instrumented root canal up to the original canal was measured with the aid of the ImageJ software (https://imagej.nih.gov/ij) (Figure 2b); and the values considered were obtained at 3 (apical third), 5 (middle third) and $7 \mathrm{~mm}$ (coronal third) up to the root apex $[11,12]$. The transportation calculation was performed by using the following equation:

$$
\mathrm{T}=\mathrm{Fi}-\mathrm{Fe}
$$

Where Fi represented the wear on the internal surface of the simulated root canal, and $\mathrm{Fe}$, the wear on its external surface. The images were analyzed blindly, by only one examiner, which was properly calibrated before images acquisition in a pilot study.

Data were submitted to test of normality (Kolmogorov \& Smirnov test), and then, they were statistically analyzed (Kruskal-Wallis, $\mathrm{p}<0.05$ - apical transportation and time to perform biomechanical preparation) using the GraphPad InStat for Windows 8 software (GraphPad Software, La Jolla, CA, USA). The statistical difference among groups was considered when $\mathrm{p}<0.05$.

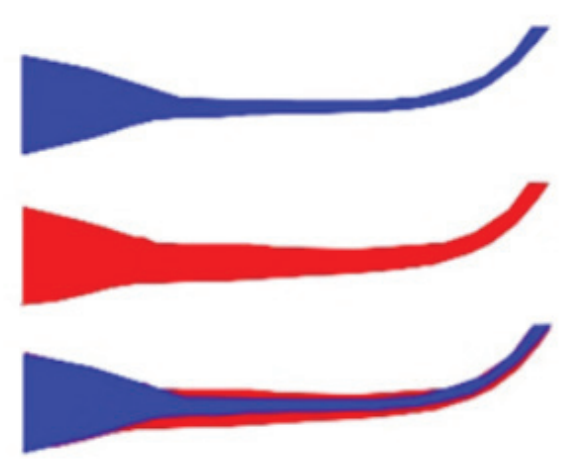

a

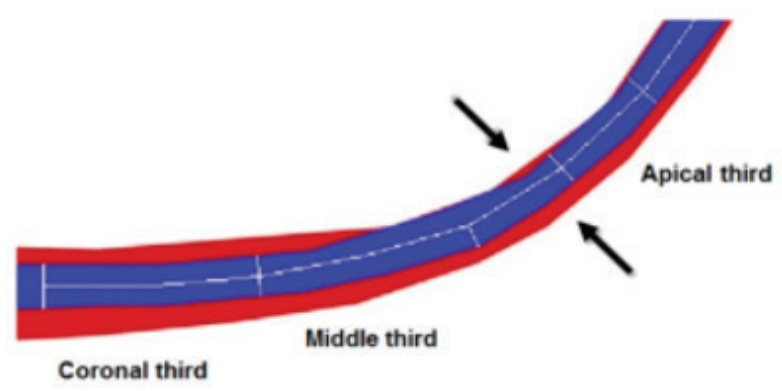

b

Figure 2 - (a) Representative images of simulated root canals colored in blue (before preparation), red (after preparation) and superimposition of the two for analyzing transportation from the original trajectory. (b) Analysis of transportation from the original trajectory of the root simulated canal in the different root thirds. Arrows indicate the external and internal walls of the simulated root canal used for calculating the transportation.

\section{RESULTS}

The graphic representation of the transportation mean values, and time required to perform preparation may be visualized in Figure 3. There was no statistically significant difference among groups at the apical third ( $\mathrm{p}>0.05)$ (Figure 3a). At the middle third, there was no statistically significant difference between GPR and R groups ( $p>0.05)$. However, GPR group presented transportation values statistically higher in comparison with GPPN and PN groups $(\mathrm{p}<0.05)$, which were similar between them $(p>0.05)$ 
(Figure 3b). At the coronal third (Figure 3c), GPR and $\mathrm{R}$ groups presented statistically similar values ( $p>0.05$ ). Only R group had a significant difference in comparison with GPPN and PN groups $(\mathrm{p}<0.05)$. There was no significant difference ( $\mathrm{p}>0.05$ ) among groups about the time spent to perform preparation of the simulated root canals (Figure $3 \mathrm{~d}$ ).

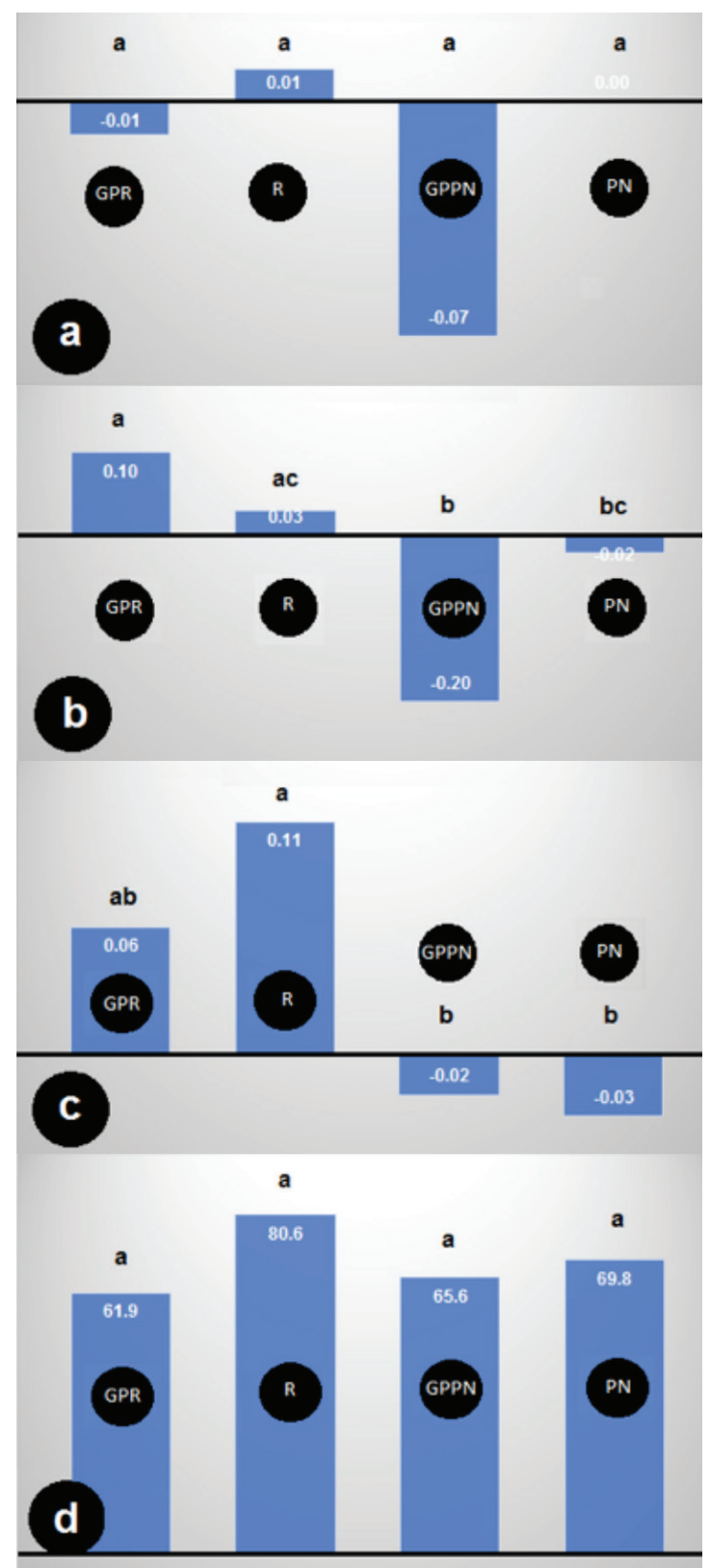

Figure 3 - Graphic representation of transportation $(\mathrm{mm})$ from the original trajectory of the simulated root canal at the different root thirds. (a) apical third; (b) middle third; (c) coronal third. (d) Graphic representation of the time required (s) for performing preparation of the simulated root canals.

* Different lower case letters over columns represent statistically significant difference (Kruskal-Wallis, $p<0.05)$.

$\mathrm{n}=15$.

\section{DISCUSSION}

The present study aimed to evaluate the effect of glide path creation on transportation promoted by instruments fabricated of NiTi and M-Wire, at the different thirds of simulated root canals. According to the results obtained, the authors could confirm that the null hypothesis tested was accepted, as glide path creation before instruments uses did not interfere with their performance, irrespective of the system tested.

The sample standardization is extremely difficult to achieve using extracted human teeth. Therefore, the use of simulated root canals in clear resin blocks to evaluate the performance of endodontic instruments pre- and postinstrumentation has several advantages in comparison with methods that use natural teeth $[13,14]$. Direct visualization of the instruments action and changes that possibly occurred in the original trajectory of the canal, due to the block transparency, are crucial factors that must be taken into consideration [13,14]. The standardization of fundamental anatomic characteristics of the root canal, such as taper, length, and angle of curvature are also relevant factors $[13,14]$. However, the use of simulated root canals in polyester resin blocks has some negative features, as the significant difference in microhardness in comparison with the dentin substrate, and the heat generated during instruments action, which may alter the physical properties of the polyester resin, compromising the performance of the instrument [15].

One of the main advantages of the systems developed over the last few years is the use of a reduced number of instruments for root canal preparation [16]. However, several studies have demonstrated that an excessive load of stress and compression forces is exerted on these instruments, leading to their premature fracture $[16,17]$. For this reason, the creation of a proper glide path; an initial flaring of the entire root canal length - from the coronal to the apical third - must be performed, ensuring that the 
instrument will passively go through the entire root canal working length $[8,9]$.

Glide path creation before root canal preparation continues to be a controversial topic in endodontics [18]. Studies have demonstrated the need of a proper glide path to allow the free advance of the instruments into the root canal, without being submitted to unnecessary stress, making root canal preparation a safer procedure, particularly in curved canals $[5,10]$. On the other hand, studies have reported that glide path creation is not necessary, particularly when single-instrument systems are used $[8,9]$.

In this study, two different systems were tested. Both were capable of performing root canal preparation with a reduced number of instruments [7]. However, the main difference between these systems was the alloy of which they were manufactured [7]. The Revo-S system was manufactured of conventional NiTi, while the ProTaper Next system was manufactured with M-Wire technology, which ensures greater flexibility of the instruments, and consequently, a higher level of resistance to cyclic and torsion fatigue [19].

It was demonstrated in the present study that glide path creation did not affect the performance of both systems. However, when the systems were compared with each other, GPPN group (glide path + ProTaper Next) had significantly higher transportation in the middle third, in comparison with the Revo-S system groups. Conversely, in the coronal third, $\mathrm{R}$ group (no glide path + Revo-S) presented higher transportation value than the ProTaper Next system groups.

Berutti et al. [20] have reported that glide path creation facilitated the action of the instrument at the most curved portion of the root canal, reducing the change in its original trajectory significantly. In the simulated root canals used in this study, the portion with the greatest curvature was located at the apical third. However, where the authors expected that the instruments would find the greatest difficulty, both systems presented similar performance, irrespective of the creation of a glide path. It is also valid to state that the transportation values observed in the present study were lower than $0.300 \mathrm{~mm}$. According to Fan et al. [21], transportation is clinically irrelevant in this situation.

Although the ProTaper Next system was manufactured of an alloy that ensures greater flexibility to the instruments, both systems tested had a similar cross-section [19]. The asymmetrical section provides a spiraling movement to the instruments, facilitating their penetration into the root canal, and promoting a similar shaping capacity [19]. Therefore, it could be emphasized that such factors also play a relevant role in maintaining the original trajectory of the simulated root canals, irrespective of preflaring before preparation; and despite the differences observed in the coronal and middle thirds.

The same could be said about the time required for performing preparation of the simulated root canals. Although Revo-S system uses one instrument more than the ProTaper Next system to perform preparation [19], this fact did not affect the time required for preparation, demonstrating the similar shaping ability of both systems.

\section{CONCLUSION}

According to the methods used in this in vitro study, the authors could affirm that none of the tested systems was capable of maintaining the original trajectory of the simulated root canals in any of the root thirds evaluated. Also, glide path creation before root canal preparation did not affect transportation promoted by the instruments.

\section{CONFLICT OF INTERESTS}

The authors deny any conflict of interests related to this study. 


\section{REFERENCES}

1. Peters $\mathrm{OA}$, Laib $\mathrm{A}$, Göhring $\mathrm{TN}$, Barbakow F.Changes in root canal geometry after preparation assessed by high-resolution computed tomography. J Endod. 2001 Jan;27(1):1-6. http://dx.doi.org/10.1097/00004770-200101000-00001.

2. Sant'Anna Júnior $A$, Cavenago $B C$, Ordinola-Zapata R, De-Deus G, Bramante CM, Duarte MA. The effect of larger apical preparations in the danger zone of lower molars prepared using the Mtwo and Reciproc systems. J Endod. 2014 Nov;40(11):1855-9. http://dx.doi.org/10.1016/j.joen.2014.06.020.

3. Isom TL, Marshall JG, Baumgartner JC. Evaluation of root thickness in curved canals after flaring. J Endod. 1995 Jul;21(7):368-71. http://dx.doi. org/10.1016/S0099-2399(06)80972-6.

4. Alencar AHG, Dummer PMH, Oliveira HCM, Pécora JD, Estrela C. Procedural errors during root canal preparation using rotary NiTi instruments detected by periapical radiography and cone beam computed tomography. Braz Dent J.2010 Nov-Dec;21(6):543-9. http://dx.doi.org/10.1590/S010364402010000600011.

5. Burklein S, Poschmann T, Schafer E. Shaping ability of different nickeltitanium systems in simulated s-shaped canals with and without glide path. J Endod. 2014 Aug;40(8):1231-4. http://dx.doi.org/10.1016/j.joen.2014.01.043.

6. Koçak MM, Ciçek E, Koçak B, Saglam N. Apical extrusion of debris using ProTaper Universal and ProTaper Next rotary systems. Int Endod J. 2015 Mar;48(3):283-6.http://dx.doi.org/10.1111/iej.12313.

7. Moreinos D, Dakar A, Stone NJ, Moshonov J. Evaluation of time to fracture and vertical forces applied by a novel Gentlefile system for root canal preparation in simulated root canals. J Endod. 2016 Mar;42(3):505-8. http:// dx.doi.org/10.1016/j.joen.2015.12.023.

8. Pasqualini D, Bianchi CC, Paolino DS, Mancini L, Cemenasco A, Cantatore $\mathrm{G}$, et al. Computed micro-tomographic evaluation of glide path with nickeltitanium rotary PathFile in maxillary first molars curved canals. J Endod. 2012 Mar;38(3):389-93. http://dx.doi.org/101016/j.joen.2011.11.011.

9. Elnaghy AM, Elsaka SE. Evaluation of root canal transportation, centering ratio, and remaining dentin thickness associated with ProTaper Next instruments with and without glide path. J Endod. 2014 Dec;40(12):2053-6. http://dx.doi.org/10.1016/j.joen.2014.09.001.

10. de Carvalho GM, Sponchiado Junior EC, Garrido AD, Lia RC, Garcia Lda F,Marques AA. Apical transportation, centering ability, and cleaning effectiveness of reciprocating single-file system associated with different glide path techniques. JEndod. 2015 Dec;41(12):2045-9. http://dx.doi. org/10.1016/j.joen.2015.09.005.

11. Wu H, Peng C, Bai Y, Hu X, Wang L, LiC. Shaping ability of ProTaper Universal, WaveOne and ProTaper Next in simulated L-shaped and S-shaped root canals. BMC Oral Health. 2015 Mar 1;15:27.http://dx.doi.org/10.1186/s12903-015-0012-z.
12 Gonçalves AN, da Frota MF Sponchiado Júnior $\mathrm{EC}$, de Carvalho FM, da Fonseca Roberti Garcia L, Franco Marques AA. Apical transportation of manual NiTi instruments and a hybrid technique in severely curved simulated canals. J Conserv Dent. 2015 Nov-Dec;18(6):436-9. http://dx.doi. org/10.4103/0972-0707.168796

13. Dummer PM, Alodeh MH, al-Omari MA. A method for the construction of simulated root canals in clear resin blocks. Int Endod J. 1991 Mar;24(2):63-6. http://dx.doi.org/10.1111/.j.1365-2591.1991.tb00809.x.

14. Bryant ST, Thompson SA, al-Omari MA, Dummer PM. Shaping ability of ProFile rotary nickel-titanium instruments with ISO sized tips in simulated root canals: part 1. Int Endod J. 1998 Jul;31(4):275-81. http://dx.doi. org/10.1046/j.1365-2591.1998.00153.x.

15. Silva EJ, Muniz BL, Pires F, Belladonna FG, Neves AA, Souza EM, De-Deus G. Comparison of canal transportation in simulated curved canals prepared with ProTaper Universal and ProTaper Gold systems. Restor Dent Endod. 2016 Feb;41(1):1-5. doi: 10.5395/rde.2016.411.11.

16. Bürklein S, Hinschitza K, Dammaschke T, Schäfer E. Shaping ability and cleaning effectiveness of two single-file systems in severely curved root canals of extracted teeth: Reciproc and WaveOne versus Mtwo and ProTaper. Int Endod J. 2012 May;45(5):449-61. http://dx.doi.org/10.1111/j.13652591.2011.01996.x.

17. Gavini G, Caldeira CL, Akisue E, Candeiro GT, Kawakami DA. Resistance to flexural fatigue of Reciproc R25 files under continuous rotation and reciprocating movement. J Endod. 2012 May;38(5):684-7.http://dx.doi org/10.1016/j.joen.2011.12.033.

18. De-Deus G, Arruda TE, Souza EM, Neves A, Magalhães K, Thuanne E, Fidel RA. The ability of the Reciproc R25 instrument to reach the full root canal working length without a glide path. Int Endod J. 2013 0ct;46(10):993-8. http://dx.doi.org/10.1111/iej.12091.

19. Lopes HP, Gambarra-Soares T, Elias CN, Siqueira JF Jr, Inojosa IF, Lopes WS, Vieira VT. Comparison of the mechanical properties of rotary instruments made of conventional nickel-titanium wire, M-wire, or nickel-titanium alloy in R-phase. J Endod. 2013 Apr;39(4):516-20. http://dx.doi.org/10.1016/j. joen.2012.12.006.

20. Berutti E, Paolino DS, Chiandussi G, Alovisi M, Cantatore G, Castellucci A, Pasqualini D. Root canal anatomy preservation of WaveOne reciprocating files with or without glide path. J Endod. 2012 Jan;38(1):101-4. http://dx.doi. org/10.1016/j.joen.2011.09.030

21. Fan B, Wu MK, Wesselink PR. Leakage along warm gutta-percha filling in the apical canals of curved roots. Endod Dent Traumatol. 2000 Feb;16(1):29-33. doi: 10.1034/j.1600-9657.2000.016001029.X.

\section{Lucas da Fonseca Roberti Garcia (Corresponding address)}

Avenida Madre Benvenuta, $n^{\circ} 388$, apto. 713, Bairro Trindade, Florianópolis - Santa Catarina - Brasil.

CEP: 88036-500

+55 (48) 3721-5843

Date submitted: 2017 Dec 13

Accept submission: 2018 Mar 06 